\title{
Short-term patient and family counselling for acute health change - an integrative literature review
}

\author{
Kristiina Raitanen ${ }^{* 1,2}$, Jari Kylmä ${ }^{1}$, Eija Paavilainen ${ }^{1,2}$ \\ ${ }^{1}$ School of Health Sciences, University of Tampere, Finland \\ ${ }^{2}$ Etelä-Pohjanmaa Hospital District, Finland
}

Received: January 8, 2015

DOI: $10.5430 /$ cns.v3n3p96
Accepted: April 12, 2015

URL: http://dx.doi.org/10.5430/cns.v3n3p96

\begin{abstract}
The purpose of this integrative literature review is to describe existing research knowledge on short-term counselling of patients and family members undergoing acute health change. The data consisted of 25 research articles and five literature reviews from the years 2003-2015, analysed using inductive content analysis. The research knowledge was found to describe elements of good patient counselling, satisfaction with the elements of good patient counselling, developing the elements of good patient counselling and impact of the patient counselling elements. Focussing on the patient's individual life situation, use of multiple counselling methods and provision of information in good interaction contribute to high quality patient counselling. Some patients and family members were satisfied with the patient counselling elements while others expressed needs for the development of the elements. The conflicting results indicate a need to develop a uniform, systematic patient counselling method, with special attention paid on the quality of counselling.
\end{abstract}

Key Words: Patient counselling, Family counselling, Short-term, Acute health change, Integrative literature review

\section{INTRODUCTION}

An acute change in health is an experience that arouses emotions, with each individual reacting differently to illness and the ensuing loss of independence. The experience is affected by the acuteness, severity and fatality of the situation. Acute illness often occurs dramatically, without warning signs or preceding events. Patients and their family members may face a crisis imbued with mixed emotions and expectations. ${ }^{[1]}$ During acute illness, characterized by unpredictability and uncontrollability, there is a risk that the patient's basic needs will not be met. ${ }^{[1]}$

Patient education and counselling are concepts commonly used in nursing science and practice to describe a profes- sional activity or process, but there are no single commonly agreed definitions. The concepts are used parallelly and synonymously to describe advising, counselling, teaching and informing patients. Typical features of patient counselling involve the context, interaction and the relationship between the provider and recipient of counselling, who are engaged in an active, goal-oriented undertaking. ${ }^{[2]}$ This study uses the more comprehensive term patient counselling throughout the text, even when referring to studies, which have employed the term patient education.

As a planned process, patient counselling involves defining counselling needs, setting goals as well as planning, evaluating and documenting the activity. A successful patient counselling process will secure patient commitment

\footnotetext{
*Correspondence: Kristiina Raitanen; Email: kristiina.raitanen@epshp.fi; Address: Etelä-Pohjanmaa Hospital District, Hanneksenrinne 7, 60220 Seinäjoki, Finland.
} 
and continuity of care. ${ }^{[3]}$ It has been proposed that essential components in high quality patient counselling include the nurse's professional responsibility, the patient's and nurse's background factors, their interactive relationship, active and goal-oriented activity, as well as the resources, adequacy and impact of counselling. ${ }^{[4]}$ High quality counselling has been found to promote patients' health, for example by improving their functional capacity, life quality, commitment to care, coping at home and independent decision-making. It can also decrease anxiety, ${ }^{[5,6]}$ depression and loneliness and help clients to better understand and remember information related to their care. ${ }^{[7]}$

A person's health affects the whole family's well-being and, reciprocally, the family's functionality affects the person's life. The role of the family becomes even more pronounced when one family member gets ill. ${ }^{[8]}$ Acute illness imposes stress on the family. ${ }^{[9]}$ Involving family members in patient counselling can promote the coping of patients, ${ }^{[10]}$ especially since family members may not be familiar with the health service and its practices and have an increased need for information. The term family member refers members of the family, companions or other persons that are close to the patient. In this literature review, patients themselves have defined who their family members are. ${ }^{[8,11]}$

Multiple methods should be used to maximize the impact of patient counselling. The choice of methods is affected by a number of factors, for example by the client's ability to assimilate information and by the goal defined for counselling. Most commonly, patient counselling is provided orally and supported by material in a written form. ${ }^{[7]}$ To be effective, the written material must be easy to read and comprehend. ${ }^{[12]}$ Individualised counselling is often the most effective learning method and it is commonly appreciated by patients. It is based on the individual's needs and makes it easier for nurses to motivate and encourage patients to become active. Individualised counselling also allows continuous feedback and facilitates the creation of an open atmosphere. Good reciprocal interaction provides patients with an opportunity to ask questions, correct misunderstandings and receive support from nursing staff. ${ }^{[7]}$

In this integrative literature review, the term short-term patient and family counselling refers to a contact of limited duration between nursing staff, patients and their family members. The overall time available for informing and counselling patients and family members is limited. Short-term counselling not only occurs in acute care settings, but also at outpatient clinics and in intensive care units, as patients undergo sudden changes. Consequently, the data selected for this study covers emergency clinics, outpatient clinics and

Published by Sciedu Press intensive care units.

Counselling has been studied extensively, but not yet exhaustively from the viewpoint presented in this review. This integrative literature review, systematically searching and integrating all available research evidence on what is known on this topic will be useful in developing short-term patient and family counselling for acute changes in health. More than ever, nurses are expected to demonstrate competence in patient and family counselling. According to Kääriäinen, ${ }^{[4]}$ for example, patients and their family members require support and adequate information and counselling to be able to cope with the changing situations. Patients have the right to receive counselling and nurses have the duty to provide it, based on good professional practice and on the principle of health promotion. Nowadays, promoting patient autonomy by counselling is imperative, as hospitalisation periods are shorter and patients more heterogeneous, often suffering from multiple problems. ${ }^{[4]}$

\section{Purpose of the study}

This integrative literature review aims at describing existing research knowledge of short-time counselling of patients and family members, who face an acute change in health. The research question is: What is known of short-time counselling of patients and their family members for acute changes in health?

\section{METHODS}

This study uses the five-stage integrative review method proposed by Whittemore and Knafl ${ }^{[13]}$ involving problem identification, literature search, data evaluation, data analysis and reporting the results. According to Polit and Beck, ${ }^{[14]}$ integrative reviews can be used for comprehensively bringing together data on a given subject area from different perspectives around the topic, for evaluating the underpinning evidence base and for drawing conclusions regarding the prevailing state of research. Integrative methods are useful for gaining an extensive overall picture of a subject area ${ }^{[15]}$ and they can be used as a basis for further research or developmental activities.

\subsection{Database search and choice of articles}

Data search was performed with assistance from an information specialist using the databases Melinda, Medic, Cinahl, Pubmed and Psycinfo. The initial search yielded a limited number of articles, so a wider perspective with new search terms was adopted and several searches carried out for all databases, excepting Pubmed. A manual search was also performed involving national nursing scientific journals and reference lists of articles already selected for the review. 
Figure 1 lists the databases, search terms and number of articles accepted throughout the process. Only research articles published in the years 2003-2015 in Finnish or English were deemed eligible. Further inclusion criteria for articles were that they provided an answer to the research question and targeted adult patients with adult family members. Overlapping studies were excluded, as well as research conducted in a ward or in other long-term care. The other exclusion factors were end-of-life patient counselling, child or psychiatric patients and patient counselling provided by medical staff only. Some studies found to be of poor quality were also excluded.

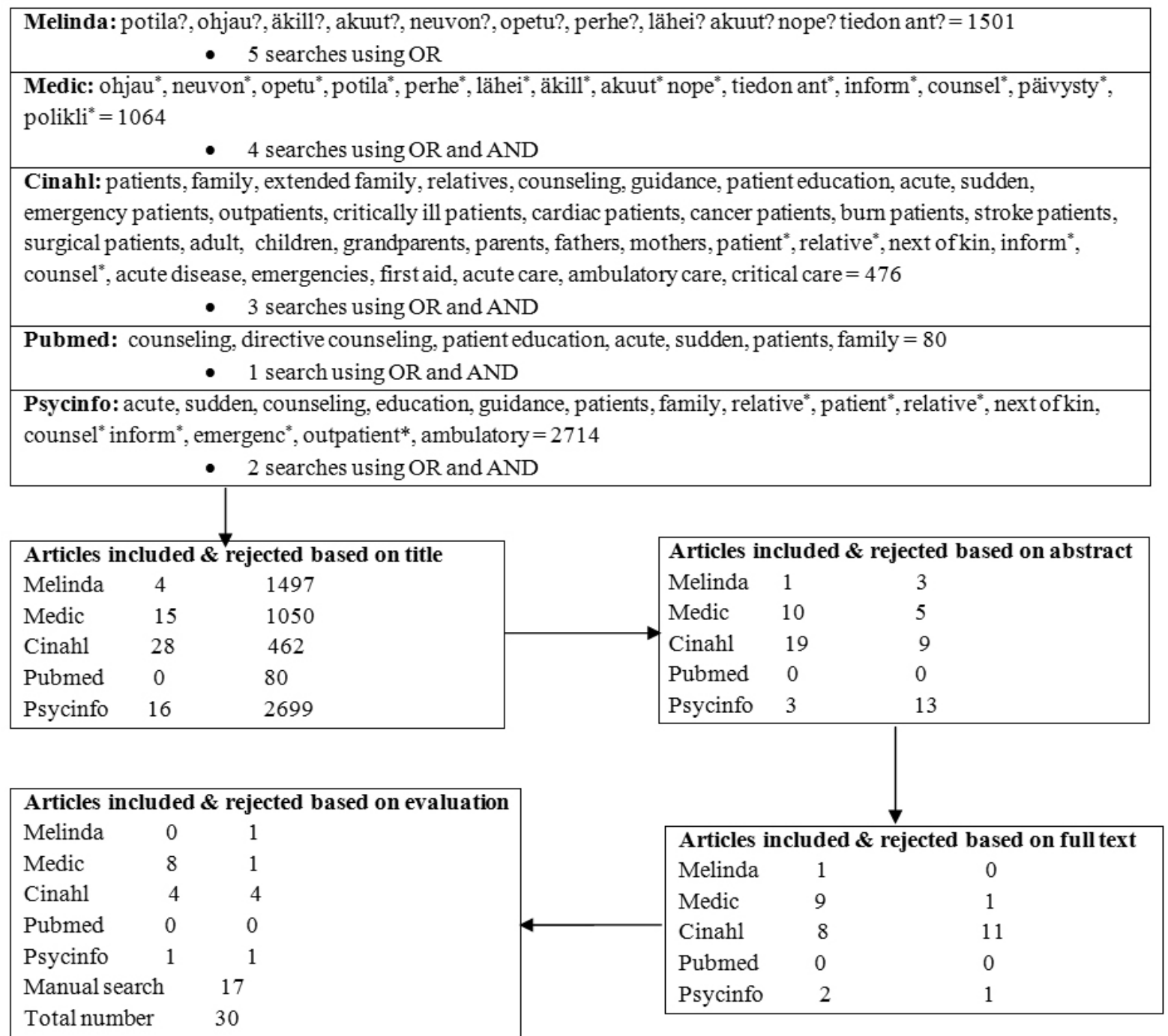

Figure 1. Database search for articles

\subsection{Search results}

The research data $(n=30)$ consists of qualitative $(n=7)$ and quantitative $(n=18)$ studies and literature reviews $(n=5)$ conducted in Finland $(n=15)$, United States $(n=8)$, Belgium $(n=2)$, Sweden $(n=2)$, Taiwan $(n=1)$, Australia $(n=1)$ and Canada $(n=1)$. The sample size varied between 6 and 62 in qualitative studies and between 50 and 3,301 in quantitative studies. The number of articles included in the five literature reviews ranged between 12 and 22, except that one review did not state the number of articles discussed. The studies had used grounded theory, phenomenology, content analysis and various statistical methods to analyse data.

\subsection{Data evaluation}

All research articles were critically appraised using the criteria outlined by Joanna Briggs Institute. ${ }^{[16]}$ The articles finally selected are of high quality; they all reached a minimum of $60 \%$ of total points in the evaluation. In the appraisals conducted using the Qualitative Assessment and Review Instrument (QARI), the quantitative MAStARI Instrument for 
randomized control/pseudo-randomized trials and the Instrument for Systematic Reviews, the score varied between 6 and 10 out of 10 points, with a major part of the articles gaining 8 points. In the appraisal conducted using the quantitative MAStARI Instrument for descriptive and case study designs, the score varied between 6 and 8 out of 9 , with nearly half of the articles gaining 8 points and the rest 6 or 7 points.

\subsection{Data analysis}

Inductive content analysis was used to analyse the data. ${ }^{[17,18]}$ Text segments that answered the research question were identified, reduced and assigned to categories according to their content. The categories were appropriately labelled and then combined into broader categories according to content. Fi-

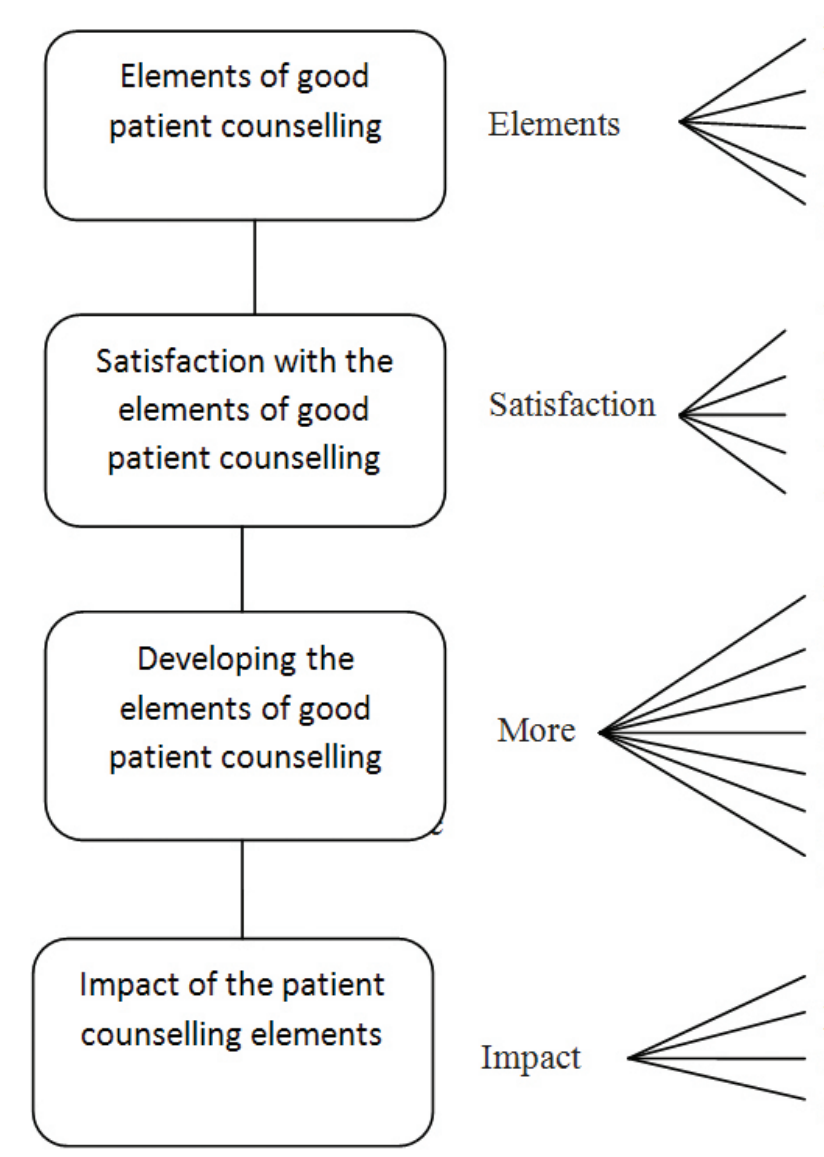

nally, the upper level categories were given labels. ${ }^{[19]}$

\section{RESULTS}

As a result of the literature review, short-term patient and family counselling for acute health changes was found to involve the following: Elements of good patient counselling, satisfaction with the elements of good patient counselling, developing the elements of good patient counselling and impact of the patient counselling elements. The elements depicted in the uppermost part of the figure constitute a foundation for counselling. These elements are associated with the other main categories: satisfaction with the elements of good patient counselling as well as the development and impact of patient counselling (see Figure 2).

patient-centred, individualised counselling

wide variety of counselling methods

counselling provided by various professionals

good interaction

high quality provision of information

with interaction

with counselling methods

with counselling during waiting time

with counselling for care of illness

with counselling for follow-up care

resources for counselling

information during waiting time

counselling for the care of health problems

high quality provision of information

counselling for follow-up care

good interaction

counselling to support family members' coping

impact of the information delivered

positive psychological impact

impact on patient's influence

impact on information received by family members

Figure 2. Elements of good patient counselling

\subsection{Elements of good patient counselling}

In studies analysed for this literature review, patient-centred, individualised counselling was presented as a good patient counselling method. Studies revealed, among other things, that hospital staff were found competent in providing individual counselling orally ${ }^{[20]}$ and that most counselling situations were individualised. ${ }^{[21]}$ According to a study, even family members received face-to-face information in the waiting room. ${ }^{[22]}$ Kääriäinen, et al. ${ }^{[20]}$ report that a major part of the patients were given patient-centred counselling. According to another study, patients were approached as individuals, with different capacities to assimilate information. ${ }^{[23]}$ Koonce, Giuse and Storrow ${ }^{[24]}$ report that those patients who had received counselling tailored to their learning style, 
found the information useful and gained in understanding of their condition. It was also found that patients' willingness to inform family members varied; in a study by Paavilainen, et al. ${ }^{[25]}$ approximately half of the patients agreed that their family members should be informed of their illness, current status and care by telephone.

Various counselling methods were found to be effective in meeting the clients' learning goals. Among them were lectures and instructional tools, ${ }^{[26]}$ written instructions and discussion, ${ }^{[21,26]}$ demonstration and practice techniques. ${ }^{[26]}$ Using a wide variety of counselling methods demands that staff members prepare themselves well for the counselling situations. The compatibility of information given by medical and nursing staff was found important, with various professional groups complementing each other. ${ }^{[23]}$ Instructions in a written form were essential for coping at home, ${ }^{[27,28]}$ especially for older patients. ${ }^{[21,25,28]}$ It was found that a general patient counselling brochure had helped patients to understand the stages of their care and the reasons for having to wait. ${ }^{[29]}$ Several studies assert that patients found the written instructions easy to understand ${ }^{[28,30,31]}$ and effective due to uncomplicated language. ${ }^{[26]}$

Counselling provided by various professionals means that according to a number of studies, patients and families received counselling from both nurses and doctors, ${ }^{[20,30,32,33]}$ mainly in the context of care. ${ }^{[21]}$ Family members found the information provided at the bedside comprehensible and concrete, because they were able to observe the patient's situation and see the care equipment and instruments. ${ }^{[23]}$

Good interaction, as an element of good patient counselling, had a positive impact according to Nikki and Paavilainen; ${ }^{[34]}$ clients described the atmosphere in the counselling situation using words like competent, reliable,${ }^{[20,30]}$ compassionate, encouraging and successful. ${ }^{[20]}$ Open, clear communication and provision of explanations helped to meet the needs of family members. ${ }^{[35]}$ One study reports that various modes of communication were used in counselling, involving formal, diverting and humoristic communication. ${ }^{[33]}$

High quality provision of information was important to family members. According to the literature reviewed, information has to be provided openly, ${ }^{[23,34]}$ truthfully ${ }^{[23,32]}$ and accurately. ${ }^{[36]}$ Provision of information is an essential part of patient counselling, as the need for information is one of the most important needs, ${ }^{[34,37,38]}$ especially in family members of critically ill patients. ${ }^{[34,38]}$ In a study, nearly half of nurses' workload during outpatient visits consisted of counselling ${ }^{[39]}$ and it was found imperative that patients should receive adequate information. ${ }^{[23]}$ Repetition and clear, informal language made information easier to comprehend. ${ }^{[23]}$
Timeliness of information and keeping clients up to date were also found to be of importance. Especially at the beginning of the care, the information needed to be clear and uncomplicated. ${ }^{[23,34]}$ A study reports that patient counselling started at the very beginning of the illness process. ${ }^{[40]}$ According to Verhaeghe, et al ${ }^{[38]}$ information provided as correctly and completely as possible created a foundation for realistic hope.

\subsection{Satisfaction with the elements of good patient coun- selling}

Satisfaction with interaction involves family members' satisfaction with the encounter and patients' satisfaction due to the presence of family members during counselling. According to Aura, et al. ${ }^{[41]}$ family members were content with the manner they were treated and with the staff's helpfulness, friendliness and professional support. In another study, nearly all patients wished for their companions to be present when care instructions were provided. ${ }^{[28]}$

Patients' and family members' satisfaction with counselling methods means that they were content with the counselling situation. Reported sources of satisfaction among patients included personal counselling, ${ }^{[30]}$ clarity of instructions, ${ }^{[28,30]}$ unhurried atmosphere, ${ }^{[28]}$ nurses' theoretical and practical counselling competence, ${ }^{[28,30]}$ nurses' attitude, ${ }^{[30]}$ adequacy of counselling, ${ }^{[20,21,30,42]}$ time allocated to discussion with nurses $^{[28]}$ and patient counselling setting. ${ }^{[20,25,30]}$ Several studies assert that the majority of patients appreciated patient counselling. ${ }^{[20,25,30,39]}$ Almost all family members regarded their presence in the counselling situation as important. ${ }^{[43]}$

Some studies report that patients ${ }^{[25]}$ and family members ${ }^{[43]}$ were satisfied with the counselling during waiting time. Both patients and family members were content that there was adequate counselling for the care of the illness. Patients were also found to be satisfied with sufficient counselling concerning examinations, ${ }^{[25,28,30,39]}$ procedures, ${ }^{[25,28,44]}$ care $^{[20,28,30,31]}$ and pharmaceutical care. ${ }^{[25,28,31]}$

Satisfaction with counselling for follow-up care means that according to some studies, patients were content with the counselling concerning home and follow-up care. Patients received adequate counselling at discharge from hospital. ${ }^{[25,28]}$ Hastings, et al., ${ }^{[31]}$ for example, report that patients were pleased with discharge planning. Also family members were satisfied with counselling concerning follow-up care and, according to Salminen-Tuomaala, et al. ${ }^{[43]}$ they found the counselling sufficient. One study asserts that family members expressed satisfaction with counselling concerning various services; they appreciated the various forms of support of- 
fered to patients and families by hospital. ${ }^{[32]}$ Clients had been best informed of the health services available. ${ }^{[45]}$

\subsection{Developing the elements of good counselling}

The literature review also revealed dissatisfaction with the counselling provided to patients and family members. Several targets for development were identified. To start with, patients wished for more resources for patient counselling, including additional facilities, time, staff resources and counselling competence. ${ }^{[20]}$ Lack of resources resulted in discontent; patients observed, among other things, that there was a lack of instruments and that the persons who provided counselling kept changing ${ }^{[20]}$ and the time allocated for counselling was limited. ${ }^{[20,30]}$

Some studies state that patients wished for more information during the waiting time. They wanted to have an estimate of how long they would be required to wait ${ }^{[25,46,47]}$ and information of how to act during the waiting time. ${ }^{[25,28,30]}$ Not knowing the expected length of the waiting period or reasons for having to wait caused some discontent. ${ }^{[4]]}$

A few studies disclosed a need for more counselling for the care of health problems. In one study, patients wished for more information concerning their illness, prognosis, procedures, insurance reimbursement, ${ }^{[30]}$ medication and effect of medicines. ${ }^{[25]}$ Further studies revealed that patients were dissatisfied with counselling concerning the cause of their illness, their prognosis, risk factors, treatment options, complications following the treatment, examination results, ${ }^{[20]}$ the illness, its symptoms and follow-up care. ${ }^{[46]}$ Family members wished for more information concerning changes in the patient's condition ${ }^{[34,36]}$ and recovery. ${ }^{[37]}$ Family members were also found to expect more counselling regarding the care of illness, including care of the patient, ${ }^{[35-38]}$ medication $^{[34]}$ and the expected outcomes. ${ }^{[37]}$

Both patients and family members wished for more high quality provision of information. This means that family members' wished for the information to be truthful, ${ }^{[35,38]}$ complete ${ }^{[38]}$ and open. ${ }^{[34]}$ The need to develop oral counselling was also mentioned. ${ }^{[41]}$ Dissatisfaction and insecurity were voiced by those who felt that the information provided was lacking, ${ }^{[34,38,44,47]}$ nurses' non-verbal communication in conflict with verbal information ${ }^{[48]}$ and the oral and written instructions ${ }^{[41]}$ or instructions given by various staff members $^{[30]}$ incompatible.

Patients and family members wished for more counselling for follow-up care. According to Chin-Yen, et al. ${ }^{[27]}$ to be able to cope at home, both patients and family members require information of the patient's condition and care. More specifically, some family members wanted more information

Published by Sciedu Press about transfer plans, ${ }^{[36,41]}$ orally provided counselling concerning the follow-up care, ${ }^{[45]}$ even more written instruction on the follow-up care. ${ }^{[21,34,43,45]}$

Family members' wish for more good interaction involves their wish to interact with hospital staff and to be listened to during the waiting time; according to patients, nurses should pay attention to the quality of the interactive situations. ${ }^{[34]}$ Family members' wish for a human encounter involved an idea of positive interaction. It also became evident that family members' capacity to receive information should be assessed beforehand ${ }^{[48]}$ Family members wanted to know how they could assist the patient ${ }^{[34]}$ and what could be done at the bedside. ${ }^{[36,37]}$ On the other hand, families' negative attitude towards counselling deteriorated interaction and counselling activity.

Finally, family members wished for more counselling to support their own coping. According to several studies, family members were dissatisfied with the support provided for personal coping, understanding emotions ${ }^{[41]}$ and dealing with fears ${ }^{[30]}$ and felt that they did not receive sufficient information regarding their coping. ${ }^{[1,45]}$

\subsection{Impact of the patient counselling elements}

The information delivered had a good impact, as the amount of responsible information increased. Chin-Yen, et al. ${ }^{[27]}$ report that patient counselling was the cornerstone of selfcare. According to other studies, too, patient counselling increased clients' information and responsibility for care ${ }^{[20]}$ and facilitated their decision-making. ${ }^{[37,49]}$

Patient counselling had a positive psychological impact. Families reported that being supported ${ }^{[48]}$ and becoming aware of one's resources and strengths ${ }^{[25]}$ were empowering experiences. Patient counselling was also found to improve patients' attitudes ${ }^{[20,30]}$ and commitment to care ${ }^{[25]}$ As for family members, information concerning patients affected them in multiple positive ways, for example by reducing their anxiety, ${ }^{[37,49]}$ depression and post-traumatic stress. ${ }^{[49]}$ In other words, patient counselling was found to decrease negative mood.

Finally, according to some studies, patient counselling also had some impact on patient's influence over care and on information received by family members. Counselling was to some extent found to be of benefit to decision-making concerning care. ${ }^{[20,30]}$ A study suggests that the least useful counselling involved being informed of the existence of written material at the clinic and learning where one could seek further information if required. ${ }^{[32]}$ 


\section{Discussion}

\subsection{Consideration of the results}

There is currently little research on short-term counselling of patients and family members and on counselling during acute health changes. The articles discussed in this review deal with patient counselling given in emergency and outpatient clinics and intensive care units; that is, in settings where counselling can be assumed to be of short duration and patients have undergone an acute change in health status.

The elements described in this article seem to represent the following cornerstones of good patient counselling: individualized, patient-centred activity, multiple methods, contribution of various professional groups, interaction and provision of information. Even in individualized, patient-centred counselling, however, the patients' willingness to involve family members may vary. In one study, ${ }^{[25]}$ approximately half of the patients wanted their family members to be informed of their illness, status or care. In other studies, the majority of the patients were pleased to have their family members present during patient counselling. ${ }^{[25,28]}$ Another finding is the essential role of written instructions as a patient counselling method. The study confirms that receiving information is a fundamental feature of counselling, ${ }^{[35-38]}$ which makes it all the more important to provide high quality, sufficient, comprehensible and timely information.

The study reveals both content and discontent with the elements of patient counselling. For example, patients and family members often express satisfaction with patient counselling situations, but also dissatisfaction due to insufficient information and conflicting aspects of counselling. Family members wish for more high quality provision of information and for the development of oral patient counselling. Patients commonly seem pleased with nursing staff's counselling competence, but a study by Kääriäinen, et al.$^{[20]}$ reports patients' wish for the improvement of nurses' counselling skills. Some studies document patients' satisfaction with the time resources, scope and setting of patient counselling, whereas others report patients' experiences of lacking resources and limited counselling time. According to some findings, patients are pleased with the counselling provided during waiting time, while others reveal dissatisfaction and an expectation for more information. Both patients and family members generally appear to be satisfied with counselling for the care of illness, but an analysis of their development ideas also reveals some discontent and a need to receive more information concerning illness. In a similar vein, many patients seem pleased with home care counselling, but some wish for more information on home care instructions. Family members also express content with follow-up care coun- selling, but many of them still wish for more counselling and written instructions on the patient's follow-up care. The conflicting views regarding the elements of counselling could be associated with differences in the quality of counselling but also with clients' different manners of providing feedback.

The information that patients and family members received during counselling had a positive impact, not only in the form of increased understanding but also psychologically. These results confirm the importance of patient counselling.

\subsection{Research reliability and ethics}

This literature review involves knowledge from 30 scientific publications on short-term family and patient counselling during acute health change. The search terms, selected on the basis of the research question, were as broad as possible. The electronic search process was conducted with assistance from an information specialist using the databases Melinda, Medic, Cinahl, Pubmed and Psycinfo. Several searches with a wider perspective and additional search terms were necessary to collect sufficient data. The study is an integrative literature review, which according to Torraco ${ }^{[50]}$ enables gaining information from multiples sources and perspectives. This increases the reliability of the study. The search and analytical process were described carefully to further increase reliability. Only studies written in Finnish or English were included, which may be seen as a limiting factor. ${ }^{[20]} \mathrm{How}-$ ever, the reliability of this study is strengthened by good results in the quality evaluation of the publications, carried out systematically following the quality criteria proposed by the Joanna Briggs Institute. ${ }^{[16]}$

The reliability of the results may be affected by the inclusion of some studies, ${ }^{[20,21,30,41,45]}$ in which part of the patients and family members had received counselling in a ward. Secondly, although counselling provided by medical staff only was one of the exclusion criteria, one of the articles ${ }^{[23]}$ involved doctors $(n=2)$ besides nurses $(n=18)$ and family members $(n=26)$. On the other hand, reliability is enhanced by the inclusion of five literature reviews ${ }^{[26,34,36,37,40]}$ as part of the data. Careful inductive content analysis was conducted to analyse the data. The primary author performed a preliminary analysis, whose results were discussed in the research team at several points during the analysis. The research process has been conducted honestly, using ethically sound research methods. ${ }^{[1]}$

\section{Conclusion}

The research results: elements of good patient counselling, satisfaction with the elements of good patient counselling, developing the elements of good patient counselling and impact of the patient counselling elements, can be generalised and 
applied to various patient and family counselling situations in health services. The conflicting results regarding counselling elements and their development indicate a need to develop a uniform, systematic patient counselling method. The quality of counselling appears to vary a great deal; efforts should be made to improve counselling by using multiple methods, by focussing on individual patients' life situation and by providing information in good interaction with patients and families. Success in these efforts will increase the impact of counselling. Furthermore, a shift is required from patient counselling towards family counselling. In future, there will be greater involvement of families in the care of patients, as the population is ageing, hospital periods are getting shorter and the need for home care is increasing. Nurses will be expected to develop their competence in family counselling methods. The development of an evaluation instrument is also proposed to examine the quality of patient counselling, to study and develop counselling interventions and possibly to evaluate how a future, systematic counselling method might contribute to the quality of counselling and care.

\section{REFERENCES}

[1] Kuisma M, Holmström P, Nurmi J, et al. Emergency care. [3rd ren. ed.] Helsinki: Sanoma Pro Oy; 2013. 783 p.

[2] Kääriäinen M, Kyngäs H. Concept analysis of counselling in nursing science. Hoitotiede. 2005; 17(5): 250-8.

[3] Eloranta T, Virkki S. Ohjaus hoitotyössä. [Education and counselling in nursing.] Latvia: Livonia Print; 2011. 112 p.

[4] Kääriäinen M. Potilasohjauksen laatuun vaikuttavat tekijät. [The factors associated with the quality of patient counseling.] Tutkiva Hoitotyö. 2008; 6(4): 10-5.

[5] Johansson K, Nuutila L, Virtanen H, et al. Preoperative education for orhopaedic patients: systematic review. J Advanced Nurs. 2005 50(2): 212-23

[6] Wong EM, Chan SW, Chair S. Effectiveness of an educational intervention on levels of pain, anxiety and self-efficacy for patients with musculoskeletal trauma. J Advanced Nurs. 2010; 66(5): 1120-31.

[7] Kyngäs H, Kääriäinen M, Poskiparta M, et al. Educating and counselling in nursing. 1st ed. Porvoo, Finland: Wsoy; 2007. 160 p.

[8] Åstedt-Kurki P, Jussila A-L, Koponen L, et al. Towards good nursing care of the family. 1st ed. Helsinki, Finland: WSOY Oppimateriaalit Oy; 2008. $158 \mathrm{p}$.

[9] Chui WY-Y, Chan SW-C. Stress and coping of Hong Kong Chinese family members during a critical illness. J Clin Nurs. 2007; 16: 37281. PMID:17239073. http://dx.doi.org/10.1111/j.1365-2 702.2005.01461.x

[10] Hubley J. Patient education in the developing world - a discipline comes of age. Patient Educ Couns. 2006; 61: 161-4. PMID:16533684. http://dx.doi.org/10.1016/j.pec.2005.02.011

[11] Paavilainen E. Perhe vieraana sairaalassa [The family as a visitor in hospital] in: Jallinoja R (ed.) Vieras perheessä. [Stranger in the family.] Helsinki: Gaudeamus; 2009. 291 p.

[12] Griffin J, McKenna K, Tooth L. Written health education materials: making them more effective. Aust Occup Ther J. 2003; 50: 170-7. http://dx.doi.org/10.1046/j.1440-1630.2003.00381.x

[13] Whittemore R, Knafl K. The integrative review: updated methodology. J Adv Nurs. 2005; 52 (5): 546-53. http: //dx . doi .org/10. 1111/j.1365-2648.2005.03621.x

[14] Polit DF, Beck CT. Nursing Research. Generating and assessing evidence for nursing practice. 9th ed. Philadelphia: Lippincott Williams \& Wilkins; 2012. 796 p.

[15] Flinkman M, Salanterä S. Integroitu katsaus - eri metodeilla tehdyn tutkimuksen yhdistäminen katsauksessa [Integrative review- combining research conducted by different methods] in: Johansson K, Axelin A, Stolt M, Ääri R-L (eds.) Systemaattinen kirjallisuuskatsaus ja sen tekeminen. [A systematic literature review and how to write it]
Turun yliopisto. Hoitotieteen laitoksen julkaisuja. Tutkimuksia ja raportteja A: 51. Turku, Finland: Digipaino Turun yliopisto [University of Turku]; 2007. 120 p.

[16] The Joanna Briggs Institute. Joanna Briggs Institute Reviewers' Manual: 2011. Available from: http://www.joannabriggs.edu.au/ Documents/sumari/Reviewers\%20Manual-2011.pdf

[17] Elo S, Kyngäs H. The qualitative content analysis process. J Adv Nurs. 2008; 62(1): 107-15. http://dx.doi.org/10.1111/j.1 365-2648.2007.04569.x

[18] Kylmä J, Rissanen ML, Laukkanen E, et al. Aineistolähtöisellä sisällönanalyysilla tietoa näyttöön perustuvan hoitotyön kehittämiseen. [Inductive content analysis as a method of generating knowledge for development of nursing.] Tutkiva Hoitotyö. 2008; 6(2): 23-9.

[19] Kylmä J, Juvakka T. Laadullinen terveystutkimus. [Qualitative health research.] Helsinki, Finland: Edita; 2012. 190 p.

[20] Kääriäinen M, Kyngäs H, Ukkola L, et al. Potilaiden käsityksiä heidän saamastaan ohjauksesta. [The conceptions of patients concerning counselling.] Tutkiva Hoitotyö. 2005; 3(1): 10-5.

[21] Johansson K, Leino-Kilpi H, Salanterä S, et al. Need for change in patient education: a Finnish survey from the patient's perspective. Patient Educ Couns. 2003; 51: 239-45. http://dx.doi .org/10. 1016/S0738-3991 (02) 00223-9

[22] Kutash M, Northrop L. Family members' experiences of the intensive care unit waiting room. J Adv Nur. 2007; 60(4): 384-8. http://dx.doi.org/10.1111/j.1365-2648.2007.04388.x

[23] Potinkara H, Åstedt-Kurki P. Tiedon antaminen kriittisesti sairaan potilaan läheisille. [Information given to a critical patient's next of kin.] Suomen Lääkärilehti. 2005; 60(25-26): 2779-82.

[24] Koonce T, Giuse NB, Storrow AB. A pilot study to evaluate learning style-tailored information prescriptions for hypertensive emergency department patients. J Med Libr Assoc. 2011; 99(4): 280-9. http://dx.doi.org/10.3163/1536-5050.99.4.005

[25] Paavilainen E, Salminen-Tuomaala M, Kurikka S, et al. Experiences of counselling in the emergency department during the waiting period: importance of family participation. J Clin Nurs. 2009; 18: 2217-24 http://dx.doi.org/10.1111/j.1365-2702.2008.02574.x

[26] Szpiro KM, Harrison MB, Van Den Kerkhof EG, et al. Patient education in the emergency department: a systematic review of interventions and outcomes. Adv Emerg Nurs J. 2008; 30(1): 34-49. http: //dx.doi.org/10.1097/01.TME.0000311544.03280.79

[27] Chin-Yen H, Barnard A, Chapman H. Emergency department nurses' understanding and experiences of implementing discharge planning. J Adv Nurs. 2009; 65(6): 1283-92. http://dx.doi .org/10.1111 /j.1365-2648.2009.04988.x

[28] Salminen-Tuomaala M, Kaappola A, Kurikka S, et al. Potilaiden käsityksiä ohjauksesta ja kirjallisten ohjeiden käytöstä päivystyspo- 
liklinikalla. [Patients ' perceptions of counselling and written home care instructions at the emergency department.] Tutkiva Hoitotyö. 2010; 8(4): 21-8.

[29] Messner ER, Reck DL, Curci KM. Effectiveness of a patient education brochure in the emergency department. Top Emerg Med. 2005; 27(4): 251-5

[30] Isola A, Backman K, Saarnio R, et al. Iäkkäiden kokemuksia saamastaan potilasohjauksesta erikoissairaanhoidossa. [Elderly persons' experiences of patient counseling in specialized care.] Hoitotiede. 2007; 19(2): 51-62.

[31] Hastings S, Stecguchak K, Oddone E, et al. Older veterans and emergency department discharge information. BMJ Qual Saf. 2012; 21 : 835-42. http://dx.doi.org/10.1136/bmjqs-2011-000538

[32] Nevalainen A, Kaunonen M, Åstedt-Kurki P. Syöpäpotilaan läheisen hoitohenkilökunnalta saama tiedollinen tuki polikliinisessa hoidossa. [Informational support received by cancer outpatients“ significant others from the nursing personnel.] Hoitotiede. 2007; 19(4): 192-201.

[33] Wiman E, Wikbland K, Idvall E. Trauma patients' encounters with the team in the emergency department -a qualitative study. Int J Nurs Stud. 2007; 44: 714-22. PMID:16549070. http://dx.doi.org/1 $0.1016 /$ j.ijnurstu.2006.01.014

[34] Nikki L, Paavilainen E. Läheisten hoitoon osallistuminen päivystyspoliklinikalla - kirjallisuuskatsaus. [Family members ‘ participation in care in an emergency department: review.] Hoitotiede. 2010; 22(4): 312-23.

[35] Maxwell KE, Stuenkel D, SAylor C. Needs of family members of critically ill patients: a comparison of nurse and family perceptions. Heart Lung. 2007; 36: 367-76. PMID:17845883. http: //dx.doi.org/10.1016/j.hrtlng.2007.02.005

[36] Verhaege S, Defoor T, Van Zuuren F, et al. The needs and experiences of family members of adult patients in an intensive care unit: a review of the literature. J Clin Nurs. 2005; 14: 501-9. http://dx.doi.org/10.1111/j.1365-2702.2004.01081.x

[37] Van Horn ER, Kautz D. Promotion of family integrity in the acute care setting: a review of the literature. Dimens Crit Care Nurs. 2007; 26(3): 101-7. http://dx.doi.org/10.1097/01.DCC.00 $00267803.64734 . c 1$

[38] Verhaeghe STL, Van Zuuren FJ, Defloor T, et al. How does information influence hope in family members of traumatic coma patients in intensive care unit? J Clin Nurs. 2007; 16: 1488-97. http://dx.doi .org/10.1111/j.1365-2702.2006.01807.x

[39] Palonen M, Aho AL, Koivisto A-M, et al. Hoitoisuuden yhteys potilaiden arvioihin ohjauksesta erikoissairaanhoidon aikuispoliklinikoilla. [The association between patient acuity and patients assessments about counselling in adolescent ambulatory care.] Hoitotiede. 2012; 24(2): 114-24
[40] Kaila A. Aivoverenkiertohäiriöön sairastuneen ja hänen omaisensa tukeminen ja ohjaus hoitotyössä -metasynteesi. [Support and counselling of stroke patients and caregivers in nursing literature - metasynthesis.] Hoitotiede. 2009; 21(1): 3-12.

[41] Aura M, Paavilainen E, Asikainen P, et al. Aikuispotilaiden läheisten kokemuksia hoitotyöntekijöiltä saadusta tuesta. [Experiences of the family member of an adult patient on the support received from the nursing staff.] Tutkiva Hoitotyö. 2010; 8(2): 14-21.

[42] Ekwall A, Gerdtz M, Manias E. Anxiety as a factor influencing satisfaction with emergency department care: perspectives of accompanying persons. J Clin Nurs. 2009; 18: 3489-97. http: //dx . doi .org/10.1111/j.1365-2702.2009.02873.x

[43] Salminen-Tuomaala M, Kurikka S, Korkiamäki K, et al. Potilaiden saattajien ohjauksen tarve päivystyspoliklinikalla. [Patients' escorts' need of counselling in the emergency clinic.] Hoitotiede. 2008; 20(5): 258-66.

[44] Pellikka H, Lukkarinen H, Isola A. Potilaiden käsityksiä hyvästä hoidosta yhteispäivystyksessä. [Patients' views of good nursing care in an emergency unit.] Hoitotiede. 2003; 15(4): 166-79.

[45] Mattila E, Kaunonen M, Aalto P, et al. Sairaalapotilaiden läheisten tuki ja siihen yhteydessä olevat tekijät. [Support for hospital patients' significant others and factors associated with it.] Hoitotiede. 2009; 21(4): 294-303

[46] Virtanen P, Paavilainen E, Helminen M, et al. Aivoverenkiertopotilaan tiedonsaanti ensiapupoliklinikalla. [How stroke patients get information at the emergency unit.] Hoitotiede. 2010; 22(4): 302-11.

[47] Elmqvist C, Fridlund B, Ekebergh M. On a hidden game board: the patient's first encounter with emergency care at the emergency department. J Clin Nurs. 2012; 21(17-18): 2609-16. http://dx. doi .org/10.1111/j.1365-2702.2011.03929.x

[48] Fontana JS. A sudden, life-threatening medical crisis: the family's perspective. Adv Nurs Sci. 2006; 29(3): 222-31. PMID:17139204. http://dx.doi.org/10.1097/00012272-200607000-00005

[49] Curtis JR, Ciechanowski PS, Dowey L, et al. Development and evaluation of an interprofessional communication intervention to improve family outcomes in the ICU: Contemp Clin Trials. 2012; 33: 1245-54. http://dx.doi.org/10.1016/j.cct.2012.06.010

[50] Torraco R. Writing integrative literature reviews: Guidelines and examples. Hum Resource Dev Rev. 2005; 4(3): 356-367. http: //dx.doi.org/10.1177/1534484305278283

[51] TENK, Tutkimuseettinen neuvottelukunta. [The Finnish Advisory Board on Research Integrity] Hyvä tieteellinen käytäntö ja sen loukkausepäilyjen käsitteleminen Suomessa. [Responsible conduct of research and procedures for handling allegations of misconduct in Finland.] 2012. Available from: http://www.tenk.fi/sites/te nk.fi/files/HTK_ohje_2012.pdf (24.3.2014) 